\title{
RESEARCH
}

Open Access

\section{The impacts of altitude and seed pretreatments on seedling emergence of Syrian juniper (Juniperus drupacea (Labill.) Ant. et Kotschy)}

Cengiz Yucedag ${ }^{1}$, Mehmet Cetin ${ }^{2^{*}}$ D, Halil Baris Ozel ${ }^{3}$, Adel Easa Saad Abo Aisha ${ }^{4}$, Osama B. Muragaa Alrabiti ${ }^{4}$ and Akram Mohamed Omar AL.JAMA ${ }^{4}$

\begin{abstract}
Background: Syrian juniper is an economically important species and in danger of extinction. For these reasons, the best seedling production methods of the species should be determined and its plantations should be established. The aim of the study is to examine the impacts of altitude and different pretreatment combinations of cold and warm stratifications, citric acid, shaking seeds in bottles with crushed glass, and different stimulating agents including Baikal EM1, Biohumus, Polystimulin A6 and K hormones (PS-A6 and PS-K) on seed germination of Syrian juniper. To conduct the study, the cones of the Syrian junipers were collected from three different altitudes $(1000,1200$, and $1400 \mathrm{~m}$ a.s.l.) within the boundaries of Forest Management Directorate of Bozyazı, Mersin in Turkey. The seeds were subjected to three replicates per one treatment (altitude in interaction with pretreatment). There were 100 seeds per replicate.

Results: Two-way ANOVA revealed significant effects of altitude, pretreatment, and their interaction on seedling emergence of Syrian juniper. Seeds from higher altitudes had higher germination rates in all pretreatments. The highest percent emergence (85\%) was recorded in the combination consisting of shaking with crushed glass, both cold and warm stratification, and successive application of stimulators PS-A6 and PS-K. All the treatments with most germinating seeds encompassed shaking in crushed glass or soaking in citric acid, both warm and cold stratifications, and application of stimulating agents.
\end{abstract}

Conclusions: The use of seeds from higher altitudes should be considered for seedling production of Syrian juniper due to their higher germination potential. Beyond altitudinal differences, specific pretreatments can rise germination potential more than twofold.

Keywords: Auxin, Citric acid, Cytokine, Germination, Stratification

\footnotetext{
* Correspondence: mcetin@kastamonu.edu.tr

${ }^{2}$ Faculty of Engineering and Architecture, Department of Landscape

Architecture, Kastamonu University, Kuzeykent Campus, 37150 Kastamonu,

Turkey

Full list of author information is available at the end of the article
}

\section{Springer Open}

(c) The Author(s). 2021 Open Access This article is licensed under a Creative Commons Attribution 4.0 International License, which permits use, sharing, adaptation, distribution and reproduction in any medium or format, as long as you give appropriate credit to the original author(s) and the source, provide a link to the Creative Commons licence, and indicate if changes were made. The images or other third party material in this article are included in the article's Creative Commons licence, unless indicated otherwise in a credit line to the material. If material is not included in the article's Creative Commons licence and your intended use is not permitted by statutory regulation or exceeds the permitted use, you will need to obtain permission directly from the copyright holder. To view a copy of this licence, visit http://creativecommons.org/licenses/by/4.0/. 


\section{Background}

Today, Juniperus drupacea forests are in danger of extinction and the contraction process of their forests continues. In Turkey, vegetative and generative sapling production technique, afforestation, and natural rejuvenation techniques of stubble are still not fully determined. Understanding eco-physiological limits to seed germination is a pre-requisite for successful plantation on a large scale. Without it, neither massive seedling production could be realized nor new plantations could be created. J. drupacea forests are under heavy grazing pressure. Their forests are being destroyed to obtain tar, which is sold at very high prices. Juniperus molasses, which was consumed only by the local people, was transformed into a commercial material with the increase of tourism, and the Juniper forests have become adversely affected as a result. In order to prevent the extinction of the economically important species, both the best seedling production methods should be determined and the plantations of the species should be established. Seedling regeneration is complicated by seed deep dormancy of the species.

Reproductive biology, particularly germination characteristics, is crucial to understanding how species cope with environmental variation (Baskin and Baskin 2014; Bauk et al. 2017) because it could vary depending on altitude and other factors. Juniper seedling regeneration occurs even at high altitudes where the establishment and growth of plants occur in short periods. Some species can recruit through rapid germination during less severe climatic periods (Archibold 1989). A species may extend over the large geographical area and can grow in a wide range of environments with varying climates and topography. It usually has populations adapted to the different local environmental conditions (Ghildiyal et al. 2009). Therefore, a comparison of the germination capacity of seeds from different altitudes is relevant to determine the reproductive efficiency of a species (Vera 1997).

Seed dormancy in plants can be split into five basic classes including physiological, morphological, morphophysiological, physical, and combinational (physical and physiological) dormancies (Baskin and Baskin 2004). Syrian juniper' seeds, which have an underdeveloped embryo with a physiological component of dormancy (Baskin and Baskin 2004), have morphophysiological dormancy (Yavuz and Yllmaz 2017). Up to date, several scientific studies (Gültekin et al. 2004; Gültekin et al. 2005; Gürlevik and Gültekin 2008; Yavuz and Yllmaz 2017) performing warm and cold stratification, treatment with sulfuric acid, gibberellic acid, mechanical treatment, cracking, and different sowing times have been conducted to enhance the seed germination of Syrian juniper. Kirdar and Ertekin
(2008) reported that cytokinin-like polystimulin-K and bioactive polystimulin-A6 mostly have positive effects on breaking dormancy and enhancing germination. However, in the earlier studies mentioned above, pretreatments have never been combined together for the seeds from different altitudes. Therefore, in this study, the seeds of Syrian juniper from three different altitudes were subjected to warm and cold folding and mechanical treatment, which have been tried in previous studies to combat germination of stubble seeds, different concentrations of citric acid and hormones.

\section{Materials and methods Species description}

Syrian juniper (Juniperus drupacea Ant. et Kotschy, Cupressaceae) is known as "Andiz" in Turkey. This species is similar to junipers in terms of many characteristics, but its seeds are not free and buds are covered with scales (Yaltırı 1993). It grows up to about $25 \mathrm{~m}$ in height with $100 \mathrm{~cm}$ diameter of breast height and has typically a pyramidal crown (Gültekin 2007). The species, native to the Taurus and AntiTaurus Mountains of the Mediterranean Region in Turkey, is mainly diffused in South Anatolia, Syria, Lebanon, and Anti-Lebanon (Yaltırik 1993). Its altitudinal distribution is between 600 and $1800 \mathrm{~m}$ in Turkey (Gültekin 2007) with cold winters and dry summers and is indifferent to soil type as it can grow on calcareous or granitic soil (Farjon 2010).

Syrian juniper generally occurs with Juniperus excelsa Bieb., J. foetidissima Willd, Cedrus libani A. Rich., Pinus nigra Arnold., Pinus brutia Ten., Abies cilicica Carr., Quercus L., and various shrub species (Gültekin 2007). This is a heliophilous tree with better growth in relatively open forests, provided a certain level of humidity in order to thrive. The Syrian juniper can be used to enhance the biodiversity in oak and cedar forest restoration (Douaihy et al. 2017). Furthermore, it plays a crucial role in the medicinal (Akbulut et al. 2008; Miceli et al. 2011; Akbulut 2015), cosmetic, social and environmental fields (Sa et al. 2017), in human nutrition (Akbulut et al. 2008), for foods and beverages as a natural antioxidant supplement (El-Ghorab et al. 2008), and as an ornamental tree (Farjon 2010; Yavuz and Yilmaz 2017). On the other hand, Juniperus is one of the trees that are resistant to extreme climatic and soil conditions and have a deep taproot. Due to these features, they are primarily versatile wood species used in the unproductive forest areas and the wind and snow curtains (Gültekin et al. 2004).

The cone mass of Syrian juniper leads to 134 cones per kilogram. The average number of healthy embryos in seeds was 2 (Gültekin et al. 2005). 


\section{Materials}

The cones were collected from natural stands at three different altitudes $(1000,1200$, and $1400 \mathrm{~m}$ a.s.l.) within the boundaries of Forest Management Directorate of Bozyazı, Mersin, in November 2017. The cones were randomly taken from 30 trees of each altitude that were at least $50 \mathrm{~m}$ apart. About 200 cones were collected for each tree spreading all over the crown and then were mixed depending on the altitude. The cones were pretreated; they were kept moist in a $4{ }^{\circ} \mathrm{C}$ refrigerator without being desiccated for 20 days. The seeds were extracted from cones prior to being subjected to pretreatments.

\section{Methods}

The seeds were subjected to three replicates per one treatment (altitude in interaction with pretreatment). There were 100 seeds per replicate. The pretreatment combination consisted of two factors, namely, altitude and pretreatment methods. The experiment included 18 treatments combining two factors. The first pretreatment (I) was a control without being applied any further manipulation (Table 1). Prior to the experiment, the viability of non-germinating seeds was checked using the float test.
The morphological dormancy was removed either by shaking of seeds in bottle with crushed glass for $2 \mathrm{~h}$ (BCG) or by soaking in $1000 \mathrm{mg} \mathrm{L}^{-1}$ citric acid $\left(\mathrm{C}_{6} \mathrm{H}_{8} \mathrm{O}_{7}\right)$ for $100 \mathrm{~min}$ at $22-24{ }^{\circ} \mathrm{C}$ (SCA). To break the morphophysiological dormancy, either cold stratification for 220 days at $3{ }^{\circ} \mathrm{C}(\mathrm{CS})$ or warm stratification for 65 days at $35^{\circ} \mathrm{C}$ (WS) was done. To stimulate the seeds to germinate, soaking in $700 \mathrm{mg} \mathrm{L}^{-1}$ Baikal EM1 for 25 days (SBE), soaking in $700 \mathrm{mg} \mathrm{L}^{-1}$ Biohumus for 25 days (SBH), soaking in $700 \mathrm{mg} \mathrm{L}^{-1}$ polystimulin A6 for 25 days (SPA), and soaking in $700 \mathrm{mg} \mathrm{L}^{-1}$ polystimulin $\mathrm{K}$ for 25 days (SPK) were used (Table 1).

Seeds were stratified in a beaker containing sand moistened with distilled water and stored in a refrigerator at $3{ }^{\circ} \mathrm{C}$ (cold stratification). They were incubated at $35^{\circ} \mathrm{C}$ for warm stratification. Polystimulins (PSs) are the synthetic high-molecular-weight plant growth regulators. PS-A6 and PS-K with high biological activity are similar to auxin and cytokinin, respectively. They are described as plant growth regulators (Tsatsakis et al. 1993).

Germination tests were carried out in a greenhouse where the mean temperature and humidity were $26 \pm$ $0.5^{\circ} \mathrm{C}$ and $80 \pm 5 \%$ respectively in October 2018. Mean soil temperature was $21 \pm 0.5^{\circ} \mathrm{C}$. Photoperiod was $11 \mathrm{~h}$ each day. Seeds were sown in sandy-clay loam at a depth

Table 1 Overview of pretreatment methods. All of them were applied separately to seeds originating from 1000, 1200, and 1400 $\mathrm{m}$ a.s.l., respectively

\begin{tabular}{|c|c|c|c|c|c|c|c|c|}
\hline \multirow[t]{2}{*}{ Treatment no. } & \multicolumn{2}{|c|}{ Removal of morphological dormancy } & \multicolumn{2}{|c|}{ Stratification } & \multicolumn{4}{|c|}{ Stimulator } \\
\hline & BCG & SCA & $\overline{C S}$ & WS & SBE & SBH & SPA & SPK \\
\hline \multicolumn{9}{|l|}{ I (control) } \\
\hline$\|$ & $x$ & & $x$ & & & & & \\
\hline III & $x$ & & & $x$ & & & & \\
\hline IV & $x$ & & $x$ & & $x$ & & & \\
\hline V & $x$ & & & $x$ & & $x$ & & \\
\hline $\mathrm{Vl}$ & $x$ & & $x$ & $x$ & $x$ & & & \\
\hline $\mathrm{VII}$ & $x$ & & $x$ & $x$ & $x$ & $x$ & & \\
\hline VIII & $x$ & & $x$ & & & & $x$ & \\
\hline IX & $x$ & & & $x$ & & & & $x$ \\
\hline$x$ & $x$ & & $x$ & $x$ & & & $x$ & $x$ \\
\hline$X I$ & & $x$ & $x$ & & & & & \\
\hline$X I I$ & & $x$ & & $x$ & & & & \\
\hline XIII & & $x$ & $x$ & & $x$ & & & \\
\hline XIV & & $x$ & & $x$ & & $x$ & & \\
\hline$X V$ & & $x$ & $x$ & $x$ & $x$ & $x$ & & \\
\hline $\mathrm{XVI}$ & & $x$ & $x$ & & & & $x$ & \\
\hline$X V I I$ & & $x$ & & $x$ & & & & $x$ \\
\hline$X V I I I$ & & $x$ & $x$ & $x$ & & & $x$ & $x$ \\
\hline
\end{tabular}


as twice as its size. The percent emergence of seedlings for each pretreatment was calculated by dividing the total number of seeds that germinated in each pretreatment by the number of seeds sown (excluding dead seeds) and multiplied by 100. Data were transformed using Arcsin square root and then analyzed using the model of two-way ANOVA. Statistical analyses were performed by using SPSS version 22 .

\section{Results}

Two-way ANOVA revealed significant differences for altitude $(F=425.127$; $\mathrm{df}=2)$, pretreatment $(F=121.412$; $\mathrm{df}=$ $17)$, and significant interaction of altitude and pretreatment $\left(F=6.428\right.$; $\left.\mathrm{df}=34 ; \mathrm{df}_{\text {error }}=108\right)$ at the 0.001 probability level. All sources of variation had an effect on the percent emergence with altitude as the main factor.

The mean percent emergence increased by as much as $20 \%$ from the lowest $(1000 \mathrm{~m})$ to the highest altitude, and altitude rankings were practically general among pretreatments, with the only exception of pretreatment VII consisting of shaking with crushed glass, both cold and warm stratifications, and successive applications of stimulators Baikal EM1 and Biohumus, respectively (Table 2, Fig. 1).

Table 2 Mean values and standard errors for percent emergence (\%) of the seedlings for pretreatments (PTs)

\begin{tabular}{|c|c|c|c|c|}
\hline \multirow[t]{3}{*}{ PTs } & \multicolumn{3}{|l|}{ Altitude (m) } & \multirow[t]{3}{*}{ Overall } \\
\hline & 1000 & 1200 & 1400 & \\
\hline & \multicolumn{3}{|c|}{ Mean $^{\mathrm{a}} \pm$ standard errors } & \\
\hline I (control) & $20.5 \pm 0.3 \mathrm{kl}$ & $30.3 \pm 2.7 \mathrm{~g}$ & $44.1 \pm 3.7 f g$ & $31.6 \pm 3.7$ \\
\hline II & $22.4 \pm 1.4 \mathrm{jkl}$ & $35.9 \pm 2.4 \mathrm{fg}$ & $45.1 \pm 1.9$ efg & $34.5 \pm 3.4$ \\
\hline III & $26.2 \pm 1.2 \mathrm{ghj}$ & $33.9 \pm 1.9 f g$ & $47.5 \pm 2.5 \mathrm{def}$ & $35.9 \pm 3.3$ \\
\hline IV & $24.1 \pm 1.6 h j k$ & $37.6 \pm 3.7 \mathrm{efg}$ & $43.5 \pm 3.5 f g$ & $35.1 \pm 3.3$ \\
\hline V & $33.8 \pm 1.8 \mathrm{ef}$ & $35.6 \pm 2.2 \mathrm{fg}$ & $45.4 \pm 2.9$ efg & $38.3 \pm 2.2$ \\
\hline VI & $41.7 \pm 1.9 c$ & $48.5 \pm 2.0 c$ & $78.5 \pm 1.4 a b$ & $56.2 \pm 5.7$ \\
\hline VII & $52.0 \pm 1.0 \mathrm{~b}$ & $67.9 \pm 1.4 b$ & $49.1 \pm 1.9 \mathrm{cdef}$ & $56.3 \pm 3.0$ \\
\hline VIII & $30.3 \pm 1.0 f g$ & $41.5 \pm 2.7 \mathrm{cdef}$ & $46.1 \pm 2.6 \mathrm{efg}$ & $39.3 \pm 2.6$ \\
\hline IX & $23.8 \pm 1.9 \mathrm{hjk}$ & $44.7 \pm 2.4$ cde & $43.9 \pm 2.1 \mathrm{fg}$ & $37.5 \pm 3.6$ \\
\hline$x$ & $58.1 \pm 1.5 a$ & $75.5 \pm 1.8 \mathrm{a}$ & $84.6 \pm 0.6 a$ & $72.7 \pm 4.0$ \\
\hline $\mathrm{XI}$ & $18.2 \pm 1.71$ & $35.4 \pm 2.2 \mathrm{fg}$ & $38.5 \pm 1.5 \mathrm{gh}$ & $30.7 \pm 3.3$ \\
\hline XII & $11.6 \pm 0.6 \mathrm{~m}$ & $30.1 \pm 2.4 \mathrm{~g}$ & $35.5 \pm 2.2 h$ & $25.7 \pm 3.7$ \\
\hline XIII & $38.5 \pm 1.0 \mathrm{~cd}$ & $46.0 \pm 3.3 \mathrm{~cd}$ & $54.1 \pm 3.1 \mathrm{~cd}$ & $46.1 \pm 2.6$ \\
\hline XIV & $34.8 \pm 2.6 \mathrm{de}$ & $48.5 \pm 1.5 c$ & $56.4 \pm 2.9 c$ & $46.6 \pm 3.4$ \\
\hline $\mathrm{XV}$ & $51.5 \pm 0.7 b$ & $68.0 \pm 1.6 b$ & $74.6 \pm 1.6 b$ & $64.7 \pm 3.5$ \\
\hline $\mathrm{XVI}$ & $30.3 \pm 0.6 f g$ & $40.8 \pm 2.5$ def & $46.5 \pm 3.3 \mathrm{def}$ & $39.2 \pm 2.7$ \\
\hline XVII & $27.9 \pm 1.4 \mathrm{gh}$ & $38.7 \pm 1.5$ def & $52.5 \pm 1.7 \mathrm{cde}$ & $39.7 \pm 3.6$ \\
\hline XVIII & $52.4 \pm 0.6 b$ & $66.0 \pm 2.5 b$ & $77.8 \pm 1.7 a b$ & $65.4 \pm 3.8$ \\
\hline Overall & $33.2 \pm 1.8$ & $45.8 \pm 1.9$ & $53.5 \pm 2.0$ & \\
\hline
\end{tabular}

${ }^{a}$ Means within each column followed by the same letter are not significantly different $(p<0.05)$
Across altitudes, the pretreatments were able to change germination rates more than twofold (Table 2 and Fig. 1). The highest percent emergence within all altitudes was recorded for pretreatment $\mathrm{X}$ consisting of shaking with crushed glass, both cold and warm stratifications, and successive applications of stimulators PS-A6 and PS-K, respectively. The combinations of cold or warm stratifications with shaking in crushed glass or soaking citric acid exhibited low emergence.

\section{Discussion}

We found a high effect of altitude in the performance of seeds of Syrian juniper. Besides, the pretreatments analyzed were able to enhance germination considerably in this species.

The percent emergence of Syrian juniper seedlings differed considerably among altitudes, such that seeds from high-altitude populations germinated more than those from low-altitude populations. Hence, Syrian juniper exhibited higher germination in seeds from $1400 \mathrm{~m}$. Likewise, Douaihy et al. (2017) reported that optimal altitude for J. drupacea was between 1500 and $1600 \mathrm{~m}$. Different responses in the seed germination percentage of other species along an altitudinal gradient were described. Seed germination percentage increased with the rising altitude in Calluna vulgaris and Erica cinerea (Vera 1997), Terminalia chebula and T. tomentosa (Chauhan et al. 2007), Pinus roxburghii (Ghildiyal et al. 2009), and Quercus leucotrichophora (Saklani et al. 2012).

In previous studies, the highest germination percentages for the same species were reported as $83 \%$ with sowing of excised embryos following stratification over 45 days at $11-15^{\circ} \mathrm{C}$ (Gültekin et al. 2005), $81 \%$ with the combination of warm stratification for 4 weeks and cold stratification for 9 weeks (Yavuz and Yilmaz 2017), 66\% with cracking (Gürlevik and Gültekin 2008), and 53\% with the combination of cracking and summer sowing (Gültekin et al. 2004).

Although cold and warm stratifications applied for embryo growth/radicle emergence require a considerably long period of time (Baskin and Baskin 2004), in fact, the current study and earlier studies have revealed that only prolonged stratification was not enough in seeds with morphophysiological dormancy. For instance, Yavuz and Yllmaz (2017) found that only 33\% germination percentage in seeds of species was obtained from cold stratification for 16 weeks at $4{ }^{\circ} \mathrm{C}$. In turn, either seeds of species should be sown after cold stratification over 8 weeks at $10-15^{\circ} \mathrm{C}$ as suggested by Gültekin et al. (2005) or seeds of species should be sown after being applied a combination of cold and warm stratifications and other pretreatments by considering the results from the current study. 


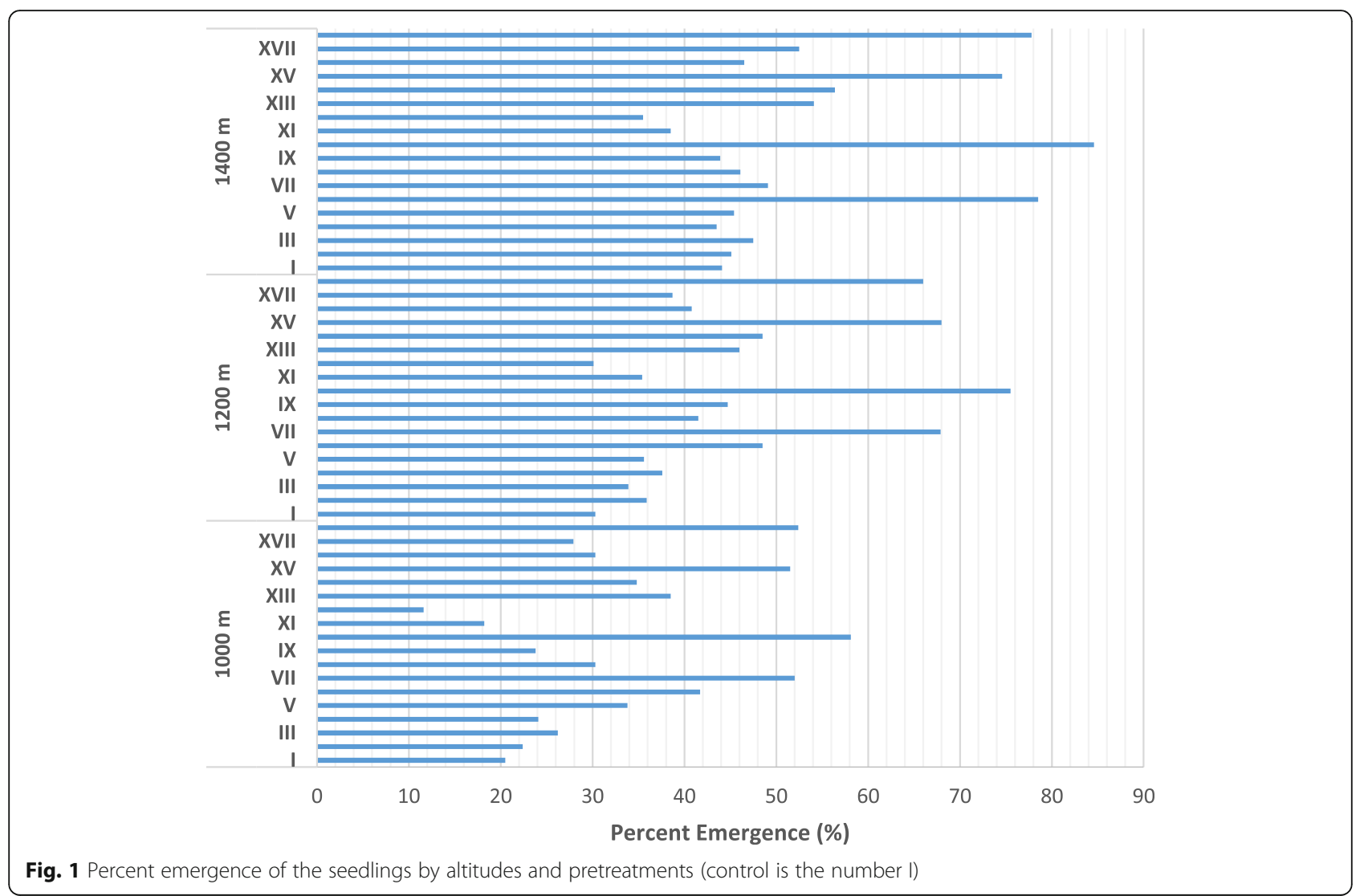

Pretreatment-XVIII consisting of soaking in citric acid, both cold and warm stratifications and successive applications of stimulators PS-A6 and PS-K, respectively showed one $(78 \%)$ of the highest percent emergence in the current study. In a similar way, Yavuz and Yilmaz (2017) reported that the seeds pre-chilled for 8 weeks and soaked with 500-ppm gibberellic acid also demonstrated high germination percentage (64\%). Unlike these results, the same species' seeds soaked both in sulfuric acid (Gültekin et al. 2005) and gibberellic acid (Yavuz and Yulmaz 2017) without another pretreatment had no germination. Tilki (2004) also stated that gibberellic acid had little effect on the germination of seeds of Laurus nobilis without pericarp but significantly increased the overall germination when used together with cold stratification.

All the treatments with most germinating seeds encompassed both warm and cold stratification. Therefore, it would be appropriate to apply different pretreatment combinations to remove the germination barrier of the species seeds. However, it should not be forgotten that although these combinations involving seed cracking processes yielded high yield percentages, it will be more practical and efficient to apply citric acid soaking as seed cracking requires intense labor and there is a possibility of damaging seed viability during cracking.

\section{Conclusions}

The results of this research have implications for the propagation of Syrian juniper. To obtain uniform germination and higher percent emergence of the seedlings in the nursery, high altitude populations $(1400 \mathrm{~m}) \mathrm{com}$ bined with bottle-shaking with crushed glass, long cold and warm stratifications (220 and 65 days, respectively), plus applying bio-stimulators (PS-A6 + PS-K for 25 days) should be used. Moreover, seeds from higher altitudes should be considered as a factor to achieve higher germination potential.

Finally, further research is needed, since seed-source altitude may have an effect not only on germination but also on growth and seedling mortality depending on the altitude of the plantation area due to genetic adaptation. Beyond altitudinal differences, pretreatment can rise germination more than twofold.

\section{Abbreviations}

PS-A6: Polystimulin A6 hormones similar to auxin; PS-K: Polystimulin K hormones similar to cytokinin; Baikal EM1: Hormones; Biohumus: Hormones; BCG: Bottle with crushed glass; CS: Cold stratification; WS: Warm stratification; SCA: Soaking in $1000 \mathrm{mg} \mathrm{L}^{-1}$ citric acid $\left(\mathrm{C}_{6} \mathrm{H}_{8} \mathrm{O}_{7}\right)$; SBE: Soaking in $700 \mathrm{mg} \mathrm{L}^{-1}$ Baikal EM1 for 25 days; SBH: Soaking in $700 \mathrm{mg} \mathrm{L}^{-1}$ Biohumus for 25 days; SPA: Soaking in $700 \mathrm{mg} \mathrm{L}^{-1}$ PS-A6 for 25 days; SPK: Soaking in $700 \mathrm{mg} \mathrm{L}^{-1}$ PS-K for 25 days

\section{Acknowledgements}

There is no acknowledgement. 


\section{Authors' contributions}

CY, MC, HBO, AESAA, OBMA, AMOA analyzed and interpreted the data. CY performed the examination of the study, and was a major contributor in writing the manuscript. CY, MC, HBO, AESAA, OBMA, AMOA analyzed the data, and wrote the manuscript. materials, AESAA, OBMA, AMOA made data collection and/or processing. All authors read and approved the final manuscript.

\section{Funding}

There is no financial support.

\section{Availability of data and materials}

All data are given in the manuscript.

Ethics approval and consent to participate

"Not applicable"

\section{Consent for publication}

"Not applicable"

\section{Competing interests}

The authors declare that they no conflict of interest.

\section{Author details}

${ }^{1}$ Faculty of Engineering-Architecture, Department of Landscape Architecture, Burdur Mehmet Akif Ersoy University, Burdur, Turkey. ${ }^{2}$ Faculty of Engineering and Architecture, Department of Landscape Architecture, Kastamonu University, Kuzeykent Campus, 37150 Kastamonu, Turkey. ${ }^{3}$ Faculty of Forestry, Department of Forest Engineering, Bartin University, Bartin, Turkey. ${ }^{4}$ Institute of Science and Technology, Graduate Programs of Material Science and Engineering, Kastamonu University, Kastamonu, Turkey.

Received: 22 April 2020 Accepted: 1 December 2020

Published online: 07 January 2021

\section{References}

Akbulut M, Çoklar H, Özen G (2008) Rheological characteristics of Juniperus drupacea fruit juice (pekmez) concentrated by boiling. Food Sci Technol Int 14(4):321-328

Akbulut S (2015) Differences in the traditional use of wild plants between rural and urban areas: the sample of Adana. Studies on Ethno-Medicine 9(2):141-150

Archibold OW (1989) Seed banks and vegetation processes in coniferous forest. In: Leck MA, Parker VT, Simpson RL (eds). Ecology of soil seed banks. Academic Press, San Diego

Baskin CC, Baskin JM (2014) Seeds: ecology, biogeography, and evolution of dormancy and germination, 2nd edn. Academic Press, San Diego

Baskin JM, Baskin CC (2004) A classification system for seed dormancy. Seed Sci Res 14:1-16

Bauk K, Flores J, Ferrero C, Perez-Sanchez R, Penas MLL, Gurvich DE (2017) Germination characteristics of Gymnocalycium monvillei (Cactaceae) along its entire altitudinal range. Botany 95(4):419-428

Chauhan S, Singh B, Bhatt BP, Todaria NP (2007) Effects of the altitude of seed origin and storage on the germination of three Terminalia species, Garhwal Himalaya, India. Forests Trees Livelihoods 17(4):339-344

Douaihy B, Tarraf P, Stephan J (2017) Juniperus drupacea Labill. stands in Jabal Moussa Biosphere Reserve, a pilot study for management guidelines. Plant Sociology 54(Suppl. 1):39-45

El-Ghorab A, Shaaban HA, El-Massry KF, Shibamoto T (2008) Chemical composition of volatile extract and biological activities of volatile and lessvolatile extracts of juniper berry (Juniperus drupacea L.) fruit. J Agric Food Chem 56(13):5021-5025

Farjon A (2010) A handbook of the world's conifers. E.J. Brill, Boston

Ghildiyal SK, Sharma CM, Gairola S (2009) Environmental variation in seed and seedling characteristics of Pinus roxburghii Sarg. from Uttarakhand, India. Appl Ecol Environ Res 7(2):121-129

Gültekin HC (2007) Syrian juniper (Arceuthos drupacea (Labill.) Ant. Et. Cotschy) and seedling production techniques. Publications of General Directorate of Forestry, Ankara, Republic of Turkey

Gültekin HC, Gezer A, Gürlevik N, Yücedağ C, Gültekin ÜG, Divrik A (2005) A study on some pretreatments to overcome the dormancy of Syrian Juniper
(Arceuthos drupacea Ant. Et. Kotschy) seeds. J Süleyman Demirel University Natural Appl Sci 9(2):84-89

Gültekin HC, Gültekin UG, Divrik A (2004) Determination of seed germination, other seed and seedling characteristics of Syrian juniper (Arceuthos drupacea (Labill.) Ant. et Kotschy.) and some recommendations. J Artvin Coruh University Forestry Faculty 5(1-2):48-54

Gürlevik N, Gültekin HC (2008) Pretreatments on germination of Syrian juniper (Arceuthos drupacea Ant. et Kotschy) seeds. J Süleyman Demirel University Forestry Faculty 2:147-157

Kirdar E, Ertekin M (2008) The role of polystimulin hormone application and stratification temperature to break the dormancy and improve seed germination for Abies nordmanniana (Stev.) Spach. Seed Sci Technol 36: $301-310$

Miceli N, Trovato A, Marino A, Bellinghieri V, Melchini A, Dugo P, Cacciola F, Donato P, Mondello L, Güvenç A, De Pasquale R, Taviano MF (2011) Phenolic composition and biological activities of Juniperus drupacea Labill. berries from Turkey. Food Chem Toxicol 49:2600-2608

Sa B, Kanj D, Raafat K, Aboul Ela M, Chalak L, Arnold-Apostolides N (2017) Ethnobotanical and economic importance of wild plant species of Jabal Moussa Bioreserve, Lebanon. J Ecosys Ecography 7(3):1-10

Saklani KP, Singh B, Bhatt BP (2012) Influence of altitude on seed and seedling characteristics in Quercus leucotrichophora A. Camus. ex. Bahadur. Silvae Genet 61(1-6):36-43

Tilki F (2004) Influence of pretreatment and desiccation on the germination of Laurus nobilis L. seeds. J Environ Biol 25(2):157-161

Tsatsakis A, Shtilman M, Allahverdiev S (1993) Water soluble polymeric system of phytohormones with slow release: synthesis and application, Patent Number EP 0609638 A1 940810, Paris.

Vera ML (1997) Effects of altitude and seed size on germination and seedling survival of heathland plants in north Spain. Plant Ecol 133:101-106

Yaltırik F (1993) Dendrology - Gymnospermae. Istanbul University, Faculty of Forestry Publications, Istanbul

Yavuz Z, YIImaz M (2017) Seed dormancy and cone and seed morphology of Syrian juniper (Juniperus drupacea Labill.) in the Eastern Mediterranean Region of Turkey. Šumarski List 5-6:257-262

\section{Publisher's Note}

Springer Nature remains neutral with regard to jurisdictional claims in published maps and institutional affiliations.

\section{Submit your manuscript to a SpringerOpen ${ }^{\circ}$ journal and benefit from:}

- Convenient online submission

- Rigorous peer review

- Open access: articles freely available online

High visibility within the field

- Retaining the copyright to your article

Submit your next manuscript at $\boldsymbol{\nabla}$ springeropen.com 